\title{
IMPACT OF LEADERSHIP ON INTERPERSONAL TRUST AT WORK IN ENTERPRISES IN BOSNIA AND HERZEGOVINA
}

UDC: 005.322:316.46(497.6)

Original Scientific Paper

\author{
Edin STRUKAN ${ }^{1}$, Edit TEREK ${ }^{2}$, Milan NIKOLIĆ \\ ${ }^{1} J U$ Pedagogical Institute of Una-Sana Canton, 77000 Bihać, Maka Dizdara 3, Bosnia and Herzegovina \\ E-mail: edinstrukan@gmail.com \\ ${ }^{2}$ The University of Novi Sad, Technical Faculty „Mihajlo Pupin“, 23000 Zrenjanin, Đure Đakovića bb, \\ Republic of Serbia
}

Paper received: 25.03.2019.; Paper accepted: 03.05.2019.

\begin{abstract}
The paper presents theoretical basics and results of concrete research of the influence of leadership dimensions on dimensions of interpersonal trust at work in enterprises in Bosnia and Herzegovina. In addition, the moderating effects of the ownership structure and the national origin of enterprises on the observed relationships were examined. The data were obtained by surveying 334 medium level managers from 103 enterprises in Bosnia and Herzegovina. The aim of this research was to determine the extent to which leadership influences interpersonal trust at work as one of the indicators of the overall effectiveness of business process management, which directly influences the scope and intensity of organizational and business performance of the enterprise. Also, the task of this research was to provide certain recommendations and guidelines for leaders and managers in order to plot future plans according to these data. The basic conclusions of this research are that leaders need to lower their performance expectations, reduce punishment, improve their relationship with employees, increase rewards in line with opportunities, and refine their strategic knowledge, thinking, and action.
\end{abstract}

Keywords: Leadership, LMX, Interpersonal trust at work, Performance, Bosnia and Herzegovina.

\section{INTRODUCTION AND THEORETICAL BASICS}

In the process of increasing globalization characterized by the rapid adaptation of organisational performance to changes induced by the market environment, individual aspects of organisational behaviour, above all leadership and mutual trust, have an increasingly significant impact on business performance and different organisational outcomes of enterprises in Bosnia and Herzegovina.

Given that in recent years business leadership is in the focus of scientific interest, work will, in the context of applying management leadership competencies, deal with business leadership, which can be defined as a guide to the whole organisation or its organisational part as soon as possible. It is the leader who can cope with the organisational changes that result from global dynamics in the business environment. Therefore, change and leadership are synonyms, which is why they are the key to good leadership in relation to people as bearers of change, and the work of the leader essentially involves working with people. In this context, for good business, leaders are increasingly turning to developing high-quality interpersonal relations between the leader-member (LMX leadership), then introducing changes to organisation and business to adequately track changes in the business environment (transformational leadership) as to develop some aspects of organisational behaviour (mutual trust) in order to increase the key business performance in their organisations to the highest level.

Essentially, regardless of the multitude of definitions, the key components of leadership can be the following: (a) Leadership is a process, (b) Leadership is influenced, (c) Leadership is reflected in the context of the group, (d) 
Leadership is assumed to be goals, and in this context, the most appropriate definition of leadership is that leadership is the process in which an individual impacts on the group to achieve a common goal (Northouse, 2008). If the task of the leader proved to be quite scattered, then it could be said that it reflected on two key things, overlook of the situation and taking action. However, in the business world there is a clear boundary between leaders and managers, and most commonly, as it is stated in most literature in this area, managers are doing the right thing, and the leaders are doing the things right, with the assertion that a good business organisation needs a good manager and a good leader, and they are not a threat to each other, but on the contrary, they are complementary, but each with its own position and role in the organisation: the manager is the administrator, the leader is an innovator, the manager maintains and the leader develops, the manager is focused on the system and structure, and the leader on the people, the manager develops control, and the leader trusts, the manager works with confidence, and the leader with probability, the manager deals with the present and the leader with the future.

The Leader-member exchange theory (LMX) is among the most investigated leadership theories. LMX theory measures the quality of the relationship and trust on the leader-member relationship. In LMX theory, leadership is defined as a process in whose centre there is an interaction between leaders and followers. In this theory, special attention is paid to what the correlation is like between the quality of exchange in relation to leader - member and positive results for leaders, followers (employees), groups and organisations in general (Graen \& Uhl-Bien, 1995).

Transformational leadership is part of the paradigm as new leadership in which greater attention is devoted to elements of leadership such as charisma and feeling. It is a process in which people are changing and implies an extraordinary form of effect-making through which followers are encouraged to achieve more than what is expected of them (Northouse, 2008). Therefore, the first activity of the transformational leader is the design and introduction of change. Changes in organisation are the process of changing the existing organisation to increase organisational efficiency. Change is one of the foundations of the organisation's existence and efficiency, so leaders who are able to identify the appropriate changes and then successfully implement them make their organisation significantly more flexible and innovative, are very important to organisations regardless of their structure and sector business (Struka et al., 2017).

Transactional leadership implies a static form of maintaining an existing state in which the role of the leader and the subordinate position of the follower are overregulated. Only leaders are involved in creating visions and defining the strategy, and everything runs smoothly and elaborately, and almost nothing leaves the case or self-initiative. Changes are created and only happen to certain limits, when and how much has to be done. This style is not popular and is not suited to modern business conditions.

Consultative literature on leadership and leadership influence on different organisational outcomes, as well as the results of concrete research, confirm that the overall performance of an enterprise depends on a higher or lower quality of leadership. Particularly significant influence has been detected on the formation of employees' attitudes toward business goals, which is manifested through the mutual trust of employees. The influence of leadership on various business performance is the subject of numerous researches (Avey et al., 2011; Carmeli e al., 2011; Ling, et al., 2008a). Part of the research suggests a positive impact of LMX leadership theory on different organisational performance (Pellegrini \& Scandura, 2006; Erdogan \& Enders, 2007). The researchers found that high-quality exchange of leader-member results in a smaller departure of employees, higher grade performance, preferred tasks, better (positive) attitude towards work, greater attention and support leaders, prominent participation and faster career progression over a period of 25 years (Graen \& Uhl-Bien, 1995).

Interpersonal trust at work is one of the primary characteristics, associated with leadership (Robbins \& Judge, 2009). Leadership trust is a significant multidimensional theme of the researcher and the key concept of several leadership theories. Loss of trust seriously affects the performance of a group. Leaders have to engage in building and maintaining trust among employees as well as trust between employees and management. By successfully creating and developing mutual trust in employees, leaders simultaneously create employee satisfaction and 
business efficiency. A comfortable business environment with a high level of mutual trust reflects the personal satisfaction of employees and develops a sense of belonging and dedication to the organisation. By developing mutual trust and mutual respect among members of the organisation, it contributes to an optimal working climate where employees can achieve their maximum potential. Leaders know that trust has a significant impact on the realization of each organisation's goals, and is particularly important for key business aspects, achieving greater levels of individual, organisational, and business performance.

In practice, it has been established that high-level teams of mutual trust within their members are more efficient and productive than those with a low level of trust. Also, a high degree of trust means that individual performance and performance of employees and leaders will be improved, such as efficiency and productivity, to improve some organisational performance such as job satisfaction, satisfaction with communication, and organisational dedication, and will ultimately improve business performance, and especially the key, financial.

\section{METHODOLOGICAL POSTULATE}

\section{Instruments used in research}

\section{Transformational leadership.}

Transformational Leadership Behaviour Inventory (TLI), The instrument used in this paper was developed by Podsakoff and associates (Podsakoff et al., 1990). The scale in this questionnaire measures six dimensions of the behaviour of the transformational leadership: articulating the vision, providing the appropriate model, fostering acceptance of group goals, expecting high performance, providing individualized support and providing intellectual incentives. The first three dimensions: the articulation of the vision, the provision of an appropriate model, the nurturing of the acceptance of group goals, have high intercorrelation, which is why they are merged into one construct, called the basic behaviour of the transformational leadership.

The measurement of transactional leadership in this paper has been carried out over two dimensions: part of incentive behaviour, i.e. rewarding (incentive), and part of the criminal behaviour, or punishment. A scale of four items of conditional rewards was used to measure the reward-driven behaviour (Podsakoff et al., 1984; MacKenzie et al., 2001). A three-item scale was used to measure behaviour conditioned by punishments (Podsakoff et al., 1984; MacKenzie et al., 2001).

To measure the quality of the LMX ratio, the LMX-7 questionnaire was applied. This instrument is used to measure the level of respect, trust, and commitment to the leader-member relation. The LMX-7 questionnaire has seven items, and when assessed, respondents use five points Likert scale (Graen \& Uhl-Bien, 1995).

Interpersonal trust at work. An instrument for measuring interpersonal trust at work (Cook \& Wall, 1980) It has 12 items and measures trust in the intentions and confidence in the actions of colleagues and management through 4 dimensions. Cook and Wall (1980) indicate the possibility of direct measurement of confidence through an experienced assessment or affective response of the respondents. These authors have developed an instrument for measuring mutual trust in the workplace, with which it is possible to measure confidence in intentions and confidence in ability, both associates and management. This instrument was also used during the research conducted for the purpose of writing this paper.

\section{Information on the mode and sample of research}

A survey on the influence of leadership on organisational commitment of B I H employees was carried out in such a way that respondents were medium level managers. Medium managers are taken for respondents as they have contacts with both top management and other employees. In doing so, middle managers have better insight and knowledge of the business, results, and perspectives of the enterprise than other employees.

Of the 103 enterprises covered, 55 enterprises $(53.40 \%)$ have a state ownership structure, and 48 enterprises $(46.60 \%)$ have a private ownership structure. Out of the total number of respondents $(\mathrm{N}=334), 185$ respondents $(55.39 \%)$ were employed in state-owned enterprises, and 149 $(44.61 \%)$ in private sector enterprises. Out of 103 enterprises, 86 enterprises $(83.50 \%)$ are of $\mathrm{BiH}$ 
national origin, 17 enterprises $(16.50 \%)$ have another (mainly EU origin). Out of the total number of respondents $(\mathrm{N}=334), 296$ respondents $(88.62 \%)$ were employed in enterprises of Bosnia and Herzegovina's national origin, and 38 respondents $(11.38 \%)$ in enterprises of European (EU) national origin.

\section{Objective, task, and hypothesis of the research}

The main goal of the research that led to this research was to find relevant indicators and to determine the extent to which methods, strategies, and known business leadership practices influence the effectiveness of running business processes and the mutual trust of employees in enterprises in Bosnia and Herzegovina. It was particularly important to determine whether it existed, and what is the statistical connection between the dimensions of leadership and the dimensions of unrelenting confidence.

The basic task of the research was to determine, based on the established values obtained from the questionnaire used during the research, and to present the managers with the direction in which they should go in the future in order to acquire additional competencies useful in achieving excellent results in the process of achieving better market and a competitive position for your enterprise.

Research hypotheses. Taking into account the work of the presented theoretical basis, as well as some other research in this field, the following hypotheses have been established:

H1: There is a statistically significant correlation between leadership dimensions and interpersonal trust at work dimensions.

H2: There is a statistically significant predictive effect of leading dimensions (independent variables) to interpersonal trust at work dimensions (dependent variables). In addition to the hypothesis, two research questions are put forward in the paper. Research questions are set up in research areas where moderate effects are examined because it is very difficult to assume the final result in advance. In this particular research questions are:

$R Q 1:$ Is there a moderate effect of the ownership structure of an enterprise on the relationship of leadership dimensions and interpersonal trust at work dimensions?

$R Q 2:$ Is there a moderate effect of the national origin of an enterprise on the relationship of leadership dimensions and interpersonal trust at work dimensions?

\section{RESEARCH RESULTS}

For data processing, descriptive statistics, correlation analysis, regression analysis and hierarchical regression analysis were applied in order to investigate the moderator effect of the ownership structure and national origin of the enterprise on the relation of dimension of leadership, the dimension of LMX, on the one hand, and interpersonal trust at work dimensions, on the other.

\section{Descriptive statistics}

Table 1. presents descriptive statistics for leadership dimensions, the dimension of LMX, and the dimensions of mutual trust at work. Short name for each dimension is given in the table i.e. names of dimensions, mean values, standard deviation, and Cronbach's alpha for each dimension. The values of Cronbach's alpha range from $\alpha=0.709$ to $\alpha=0.893$. 
E. Strukan Impact of leadership on interpersonal trust at work in enterprises

et al. in Bosnia and Herzegovina

Table 1: Descriptive statistics ( $N=334$ mid-level managers)

\begin{tabular}{|l|c|c|c|c|c|c|c|}
\hline \multicolumn{1}{|c|}{ Dimension } & $\begin{array}{c}\text { Short } \\
\text { name }\end{array}$ & $\mathrm{N}$ & Min & Max & Mean & $\begin{array}{c}\text { Std. } \\
\text { Dev. }\end{array}$ & $\begin{array}{c}\text { Cronbach } \\
\text { alpha }\end{array}$ \\
\hline Core transformational leader behaviour & L1 & 334 & 1,0000 & 7,0000 & 4,692615 & 1,4989682 & 0,913 \\
\hline High performance expectations & L2 & 334 & 1,0000 & 7,0000 & 4,931138 & 1,3806356 & 0,872 \\
\hline Supportive leader behaviour & L3 & 334 & 1,0000 & 7,0000 & 3,883982 & 1,5758517 & 0,963 \\
\hline Intellectual stimulation & L4 & 334 & 1,0000 & 7,0000 & 4,139970 & 1,3652090 & 0,912 \\
\hline Contingent reward behaviour & L5 & 334 & 1,0000 & 7,0000 & 3,863024 & 1,6045130 & 0,909 \\
\hline Contingent punishment behavior & L6 & 334 & 1,0000 & 7,0000 & 4,506986 & 1,4289249 & 0,912 \\
\hline Leader member exchange & LMX & 334 & 1,0000 & 5,0000 & 3,244226 &, 8982298 & 0,919 \\
\hline Trust in intentions of Colleagues & ITW1 & 334 & 1,0000 & 7,0000 & 4,704591 & 1,4170039 & 0,922 \\
\hline Trust in intentions of Management & ITW2 & 334 & 1,0000 & 7,0000 & 3,972056 & 1,7129366 & 0,901 \\
\hline Confidence in actions of Colleagues & ITW3 & 334 & 1,0000 & 7,0000 & 4,643713 & 1,4548500 & 0,931 \\
\hline Confidence in actions of Management & ITW4 & 334 & 1,0000 & 7,0000 & 4,186627 & 1,7938744 & 0,961 \\
\hline & Valid N & 334 & & & & & \\
\hline
\end{tabular}

\section{Correlation analysis}

Table 2 shows the results of the correlation analysis between the leadership dimensions, the LMX dimension, on the one hand, and the interpersonal trust at work dimensions on the other. Pearson correlation was used. Statistically significant correlations are indicated as follows: * $\mathrm{p}<0.05 ; * * \mathrm{p}<0.01$. It can be noted that most correlations are statistically significant and that $* *$ $\mathrm{p}<0.01$.

Table 2: Coefficients of correlation between the leadership dimensions, LMX dimension and interpersonal trust at work dimensions

\begin{tabular}{|c|l|l|l|l|}
\hline & ITW1 & ITW2 & ITW3 & ITW4 \\
\hline L1 &, $354^{* *}$ &, $578^{* *}$ &, $225^{* *}$ &, $605^{* *}$ \\
\hline L2 &, $196^{* *}$ &, $134^{*}$ &, $219^{* *}$ &, $149^{* *}$ \\
\hline L3 &, $435^{* *}$ &, $694^{* *}$ &, $319^{* *}$ &, $618^{* *}$ \\
\hline L4 &, $390^{* *}$ &, $646^{* *}$ &, $332^{* *}$ &, $663^{* *}$ \\
\hline L5 &, $452^{* *}$ &, $735^{* *}$ &, $406^{* *}$ &, $664^{* *}$ \\
\hline L6 &, $165^{* *}$ &, $110^{*}$ &, $193^{* *}$ &, $132^{*}$ \\
\hline LMX &, $511^{* *}$ &, $786^{* *}$ &, $360^{* *}$ &, $741^{* *}$ \\
\hline
\end{tabular}

\section{Regression analysis}

Multiple regression analysis was applied to determine the predictive effect of leadership dimensions and LMX dimension (independent variables) on interpersonal trust at work dimensions (dependent variables). The results of this regression analysis are shown in Table 3.
The ownership structure of the enterprise as the moderator of the observed relationships

The results of the correlation analysis between the leadership dimensions, the LMX dimension and the interpersonal trust at work dimensions, for state-owned and private enterprises, are shown in Table 4.

Table 3: Regression analysis (Dependent variables: interpersonal trust at work dimensions, Independent variables: leadership dimensions and LMX dimension)

\begin{tabular}{|c|c|c|c|c|c|c|c|c|c|c|}
\hline & & & & Indep. & & & & & & \\
\hline Dep. & L1 & L2 & L3 & L4 & L5 & L6 & LMX & $\mathrm{R}^{2}$ & F & Sig. \\
\hline & & & & $\beta$ & & & & & & \\
\hline ITW1 &,- 057 &, 089 &, 153 &,- 015 &, 047 &, 083 & $\mathbf{, 3 9 1}$ & 0,292 & 19,242 &, 000 \\
\hline ITW2 &,- 006 &,- 029 & $\mathbf{, 1 3 9}$ &, 106 & $\mathbf{2 1 3}$ &, 034 & $\mathbf{4 5 1}$ & 0,672 & 95,440 &, 000 \\
\hline ITW3 &,- 114 &, 111 &, 086 &, 030 & $\mathbf{2 2 9}$ &, 074 &, 155 & 0,199 & 11,606 &, 000 \\
\hline ITW4 & $\mathbf{1 0 3}$ &,- 041 &, 024 & $\mathbf{, 2 3 2}$ &, 104 &, 037 & $\mathbf{, 4 1 5}$ & 0,606 & 71,692 &, 000 \\
\hline
\end{tabular}


Table 4: Coefficients of leadership dimension correlations, LMX dimension and interpersonal trust at work dimensions, for state and private enterprises

\begin{tabular}{|c|c|c|c|c|c|}
\hline \multicolumn{2}{|c|}{ VLS } & ITW1 & ITW2 & ITW3 & ITW4 \\
\hline \multirow{4}{*}{$\begin{array}{c}1 \text { State } \\
\mathrm{N}_{\mathrm{st}}=185\end{array}$} & L1 &, $328^{* *}$ &, $584^{* *}$ &, $211^{* *}$ &, $598^{* *}$ \\
\cline { 2 - 6 } & L2 &, 116 &, 129 &, $145^{*}$ &, 100 \\
\cline { 2 - 6 } & L3 &, $438^{* *}$ &, $696^{* *}$ &, $296^{* *}$ &, $630^{* *}$ \\
\cline { 2 - 6 } & L4 &, $349^{* *}$ &, $648^{* *}$ &, $308^{* *}$ &, $688^{* *}$ \\
\cline { 2 - 6 } & L5 &, $448^{* *}$ &, $737^{* *}$ &, $369^{* *}$ &, $689^{* *}$ \\
\cline { 2 - 6 } & L6 &, 129 &, $190^{* *}$ &, $148^{*}$ &, $208^{* *}$ \\
\cline { 2 - 6 } & LMX &, $537^{* *}$ &, $789^{* *}$ &, $376^{* *}$ &, $756^{* *}$ \\
\cline { 2 - 6 } & L1 &, $393^{* *}$ &, $566^{* *}$ &, $236^{* *}$ &, $595^{* *}$ \\
\cline { 2 - 6 } & L2 Private &, $317^{* *}$ &, 111 &, $317^{* *}$ &, 158 \\
\cline { 2 - 6 } $\mathrm{N}_{\mathrm{pr}}=149$ & L3 &, $430^{* *}$ &, $697^{* *}$ &, $351^{* *}$ &, $615^{* *}$ \\
\cline { 2 - 6 } & L4 &, $447^{* *}$ &, $640^{* *}$ &, $360^{* *}$ &, $624^{* *}$ \\
\cline { 2 - 6 } & L5 &, $461^{* *}$ &, $730^{* *}$ &, $446^{* *}$ &, $621^{* *}$ \\
\cline { 2 - 6 } & L6 &, $212^{* *}$ &,- 019 &, $245^{* *}$ &,- 010 \\
\cline { 2 - 6 } & LMX &, $478^{* *}$ &, $783^{* *}$ &, $333^{* *}$ &, $711^{* *}$ \\
\hline
\end{tabular}

$* \mathrm{p}<0.05 ; * * \mathrm{p}<0.01$.

In order to examine the moderator effect of the ownership structure, a hierarchical regression analysis was used, examining the significance of the regression coefficient with the product of the predictor variable for independent variable: leadership dimensions, LMX dimension, and dependent variable: interpersonal trust at work dimensions and moderator variables of the ownership structure. The results of the hierarchical regression analysis ( $\mathrm{R}$ square change and $\mathrm{F}$ change), and only results confirming the moderate effect of the structure are presented in Table 5 .

Table 5: Hierarchical regression analysis (R square change and F-change) with the ownership structure as a moderator (only couples confirming the influence of the moderation of the ownership structure)

\begin{tabular}{|c|c|c|c|}
\hline Independent & Dependent & R square change & F-change \\
\hline L2 & ITW1 & 0,012 & 4,192 \\
\hline L2 & ITW3 & 0,010 & 3,640 \\
\hline L6 & ITW2 & 0,010 & 3,329 \\
\hline L6 & ITW4 & 0,010 & 3,598 \\
\hline
\end{tabular}

The national origin of the enterprise as a moderator of the observed relationships

The results of the correlation analysis between the leadership dimensions, the LMX dimension and the interpersonal trust at work dimensions, for domestic and foreign enterprise, separately, are shown in Table 6 .

For the moderator, the national origin of the enterprise, a hierarchical regression analysis was used, which examined the significance of the regression coefficient with the product of the predictor variable for independently variable: leadership dimensions, LMX dimension and dependent variable: interpersonal trust at work dimensions, and moderator variables of the national origin of the enterprise. The results of hierarchical regression analysis ( $\mathrm{R}$ square change and F-change) and only the results in which the moderate effect of the national origin of the enterprise was confirmed are presented in Table 7. 
Table 6: Coefficients of leadership dimension correlations, LMX dimension and interpersonal trust at work dimensions, for domestic and foreign enterprises

\begin{tabular}{|c|c|c|c|c|c|}
\hline \multicolumn{2}{|c|}{ NACP } & ITW1 & ITW2 & ITW3 & ITW4 \\
\hline \multirow{4}{*}{$\begin{array}{c}\text { 1 BIH } \\
N_{\text {BIH }}=296\end{array}$} & L1 &, $347^{* *}$ &, $572^{* *}$ &, $231^{* *}$ &, $604^{* *}$ \\
\cline { 2 - 6 } & L2 &, $198^{* *}$ &, $128^{*}$ &, $226^{* *}$ &, $125^{* *}$ \\
\cline { 2 - 6 } & L3 &, $417^{* *}$ &, $694^{* *}$ &, $313^{* *}$ &, $637^{* *}$ \\
\cline { 2 - 6 } & L4 &, $377^{* *}$ &, $655^{* *}$ &, $335^{* *}$ &, $668^{* *}$ \\
\cline { 2 - 6 } & L5 &, $441^{* *}$ &, $737^{* *}$ &, $407^{* *}$ &, $670^{* *}$ \\
\cline { 2 - 6 } & L6 &, $161^{* *}$ &, $117^{*}$ &, $190^{* *}$ &, $134^{*}$ \\
\cline { 2 - 6 } & LMX &, $531^{* *}$ &, $792^{* *}$ &, $389^{* *}$ &, $754^{* *}$ \\
\hline \multirow{4}{*}{ Foreign } & L1 &, $440^{* *}$ &, $630^{* *}$ &, 177 &, $608^{* *}$ \\
\cline { 2 - 6 } & L2 &, 201 &, 178 &, 163 &, $345^{*}$ \\
\cline { 2 - 6 } & L3 &, $598^{* *}$ &, $695^{* *}$ &, $371^{*}$ &, $468^{* *}$ \\
\cline { 2 - 6 } & L4 &, $517^{* *}$ &, $577^{* *}$ &, 310 &, $621^{* *}$ \\
\cline { 2 - 6 } & L5 &, $578^{* *}$ &, $720^{* *}$ &, $404^{*}$ &, $611^{* *}$ \\
\cline { 2 - 6 } & L6 &, 241 &, 018 &, 221 &, 082 \\
\cline { 2 - 6 } & LMX &, $376^{*}$ &, $731^{* *}$ &, 103 &, $618^{* *}$ \\
\hline
\end{tabular}

Table 7: Hierarchical regression analysis ( $R$ square change and F-change) with the national origin of the enterprise as a moderator (only a couple confirming the influence of the national moderation origin)

\begin{tabular}{|c|c|c|c|}
\hline Independent & Dependent & R square change & F-change \\
\hline LMX & ITW3 & 0,007 & 2,818 \\
\hline
\end{tabular}

\section{DISCUSSION}

The results of descriptive statistics (Table 1) show that for leadership dimensions, dimensions L2 High-performance expectations, followed by L1 Core transformational leader behaviour and L6 Contingent punishment behaviour, have the highest average ratings. The lowest average ratings are L5 - Contingent reward behaviour and L3 Supportive leader behaviour. It can be noticed that executives expect high performance, but their supportive action towards employees is not at that level. Also, in the dimension of transactional leadership, the principle of punishment is more present than the principle of rewarding. This result is a consequence of the transition conditions in the economy of Bosnia and Herzegovina, which, among other things, is characterized by poor condition and high unemployment. All this is followed by the aspiration of a leader for greater profit, without the necessary understanding of the employees and without much opportunity (probably the desire) that the employee gets rewards. Finally, this results in an average LMX rating. The average ratings of interpersonal trust at work dimensions are consistent with previous findings. In the case of interpersonal trust at work dimensions, the situation is divided: significantly more average grades have two dimensions that relate to confidence in the intentions and actions of colleagues, in relation to the two dimensions that relate to trust in intentions and management actions. Therefore, employees trust their colleagues more than management. It can also be considered logical that employees trust their colleagues with whom they work more than the management of the enterprise, which is seen very rarely.

Correlation analysis (Table 2) shows that when it comes to trust at work dimensions, dimension LMX has the strongest impact on interpersonal trust dimensions and then follow the strengths of the following dimensions: L5 - Contingent reward behaviour, L3 - Supportive leader behaviour, L4 Intellectual stimulation, L1 - Core transformational leader behaviour, L2 - High performance expectations and, ultimately, L6 - Contingent punishment behaviour. Thus, mutual trust at work depends to a large extent on the direct relation of the leader and the followers, as well as the readiness of the leader to reward employees. Simply, good relations on a leader-to-relationship relationship certainly contribute to mutual trust in the organisation. Likewise, it seems that trust, to a large extent, can be built on the existence of appropriate rewards, that is, through the incentive behaviour of the leader in the form of employee benefits. Accordingly, the strongest correlations occur between the dimensions of LMX and ITW2 - 
Trust in the intentions of Management, as well as the dimension L5 - Contingent reward behaviour and ITW2 - Trust in the intentions of Management. Therefore, trust in the intentions of the management is best built through the quality of LMX relationships, but also adequate rewarding.

As stated above, the leadership dimensions, the convincingly weakest correlations with interpersonal trust at work dimensions, make the dimensions L6 - Contingent punishment behaviour and L2 - High-performance expectations. Penalties, obviously, cannot lead to a high level of trust in an organisation, and in particular, this relates to trust in intentions and management actions. Indeed, it is difficult to expect high trust in someone who implements the punishment system and does not find other ways to motivate employees. Likewise, the expectation of high performance somewhat less contributes to the development of trust. Employees can often interpret high-performance requirements as an attack on the quality of their previous work, their leisure time, relaxed relationships and the atmosphere at work and the like, which then leads to a somewhat lesser impact on trust, especially the confidence in intentions and management actions.

When it comes to correlations that achieve a certain dimension of mutual trust in business with dimensions of leadership, it is clearly demonstrated that ITW2 - Trust in Intentions of Management and ITW4 - Confidence in Action of Management have significantly stronger correlations than ITW1 - Trust in intentions of Colleagues and ITW3 Confidence in actions of Colleagues. As you might expect, leadership significantly influences confidence in management rather than colleagues. This result is logical: a quality LMX relationship and good leadership will surely lead to a high level of trust in the management of the organisation. The same goes for trusting colleagues, but leadership has much to do with management rather than with colleagues, so the influence of leadership on trusting colleagues is somewhat weaker.

The correlation analysis, in general, showed that the LMX dimension and dimension L5 Contingent reward behaviour, and then the dimension L3 - Supportive leader behaviour, have the greatest influence on the observed elements of organisational behaviour. These relationships suggest that, in enterprises in Bosnia and Herzegovina, transformational leadership is of the greatest importance and impact on employee satisfaction and business performance (especially the part relating to interpersonal relationships and understanding), but also the transactional leadership in the part relating to rewarding. Employees in Bosnia and Herzegovina expect leaders both to understand and reward at the same time. This is understandable. However, such expectations will often come to disappointment, because leaders who want to behave in this way are rare.

Most of the existing research significantly favours transformation in relation to transactional leadership, for example (Howell et al., 2005; Ensle et al., 2006; MacKenzie et al., 2001; Carpenter et al., 2004; Ling, et.al., 2008; Colbert, et al., 2008). These researches show the positive influence of transformational leadership on numerous organisational and business performances. However, some research also points out the importance of transactional leadership, especially in the part referring to remuneration (Hofmann, Jones, 2005; Elenkov, 2002). Thus, the results obtained here can be considered compatible with both groups of the research. The reasons for this situation should be sought in the specific transitional business conditions that currently exist in enterprises in Bosnia and Herzegovina. The standard of living of employees is low, and the fear of losing a job is general and realistic. Under such conditions, employees expect support and understanding, primarily from the leader. Then, they expect rewards, which mean a lot to them in both material and psychological terms.

The results of the regression analysis in which the dimensions of the leadership and the LMX are the dimensions of an independent variable and the dimensions of mutual confidence at the work dependent variable are shown in Table 3. All values of the corrected determination indexes $\mathrm{R} 2$ are statistically significant. Accordingly, it can be concluded that the dimension of leadership and LMX dimension realize a predictive effect on the dimensions of mutual trust at work. This confirms the hypothesis H2. The highest values of the corrected R2 determination index exist with the dimensions ITW2 - Trust in Intentions of Management and ITW4 - Confidence in actions of Management. These results are completely consistent with the results of correlation analysis (the influence of leadership dimensions and LMX dimension on the dimensions of mutual trust at work).

Individually, from the dimension of leadership, the strongest predictive effect on the dimensions of 
mutual trust at work is achieved by the dimension of LMX and dimension L5 - Contingent reward behaviour. These two dimensions have the most powerful predictive effect. These results are also fully consistent with the results of the correlation analysis. These relations were previously discussed.

In this part (in addition to the predictive effect achieved by LMX and L5 - Contingent reward behaviour, there are three more statistically significant and positive values of the coefficient $\beta$. First, the dimension L1 - Core transformational leader behaviour has a statistically significant positive predictive effect on the dimension ITW4 Confidence. In other words, the dimension L4 the intellectual stimulation has a statistically significant positive predictive effect on the dimension ITW4 - Confidence in actions of Management. From this it follows that confidence in management actions is achieved through the transformational behaviour of the leader and intellectual stimulation as well as with the quality The LMX ratio (dimension LMX also has a statistically significant and positive predictive effect on the dimension ITW4 - Confidence in actions of Management). Third, the dimension L3 Supportive leader behaviour has a statistically significant positive predictive effect on the ITW2 dimension - Trust in intentions of Management. Therefore, while confidence in management actions is built through the quality of business leaders, a clear vision, communication of the vision, intellectual stimulation and a good LMX relationship, trust in the intentions of management is built through understanding of the feelings of the employees by the leaders, adequate rewarding and through a quality LMX relationship. Confidence in management actions is more about the professional aspects of leadership, and trust in the intentions of management is more about the interpersonal and social aspects of leadership.

Tables 4. and 5. show that the moderating effect of the ownership structure of the enterprise, the relationship between the dimensions of leadership and the dimensions of mutual trust at work, is expressed in several relations. The modernization of the ownership structure of the enterprise is manifested by correlations that are more robust in private enterprises, in the effect of the L2 - Highperformance expectations dimension on ITW1 Trust in the intentions of Colleagues and ITW3 Confidence in actions of Colleagues. In addition, the moderate effect of the ownership structure of the enterprise is manifested by correlations that are significantly stronger in state enterprises, in the effect of the L6 dimension - Contingent punishment behaviour on the dimensions ITW2 Trust in the Intentions of Management and ITW4 Confidence in actions of Management. Consequently, it is not possible to make a general conclusion as to how the ownership structure of an enterprise acts as a moderator in relation to the dimensions of leadership and the dimensions of mutual trust at work. The following are discussed in more detail about the couples of the dimensions of leadership and the dimensions of mutual trust at work, in which the moderate effect of the ownership structure of the enterprise occurs.

It should be pointed out that correlation between the dimensions of leadership and the dimensions of mutual trust at work are predominantly statistically significant and strong both in state and private enterprises. Moderate action is manifested in the following cases:

(1) The L2 - High-performance expectations dimension positively and strongly affects the dimensions of ITW1 - Trust in the intentions of Colleagues and ITW3 - Confidence in actions of Colleagues, in private than in state-owned enterprises. As already noted, in private enterprises, a greater impact is assumed and greater responsibility for the results achieved. Under such conditions, employees are more dependent on their colleagues, their work, their intentions, and actions. Consequently, the expectation of high performance contributes to the development of greater confidence in colleagues in private than in state-owned enterprises.

(2) The dimension L6 - Contingent punishment behaviour is more pronounced on the dimensions of ITW2 - Trust in Intentions of Management and ITW4 - Confidence in actions of Management, in state enterprises, while in private enterprises this relationship is slightly negative. Given that, as it has already been established, penalties are more difficult to apply in private enterprises, punishments in private enterprises will to a greater extent negatively affected trust in management, both its intentions and actions.

In general, the moderate effect occurs in certain relations and the impact on mutual trust at work is twofold: in the case of the L2 dimension - Highperformance expectations is stronger with private enterprises, and with the dimension L6 Contingent punishment behaviour is stronger with 
state enterprises. Previous findings can be considered as a response to the raised research question RQ1. Private enterprises have greater opportunities to show leadership in action, that is, leadership is specific to certain aspects of mutual trust, while in state-owned enterprises there are higher limitations for leaders, primarily in the form of legal regulations. At the same time, there is a higher sensitivity to penalties in private enterprises, probably because dissatisfaction is more easily concentrated on the personality of the owner, rather than towards the state, then because of the greater fear of loss of work, and possibly because in private enterprises, employees are aware that there are many possibilities for reward, and punishment further frustrates them.

Tables 6. and 7. show that there is no expressive moderate effect of the national origin of the enterprise on the relation between the dimensions of leadership and the dimensions of mutual trust at work. A moderate fact is the national origin of an enterprise only in one case:

(1) The LMX dimension positively and strongly affects the dimension ITW3 - Confidence in actions of Colleagues, in enterprises in Bosnia and Herzegovina, as in foreign enterprises. In enterprises from Bosnia and Herzegovina, a good LMX relationship probably contributes to greater confidence in colleagues' actions. This result may reveal the fact that a good LMX relationship in enterprises from Bosnia and Herzegovina is actually positively focused on colleagues (and thus more sincere) than a good LMX relationship in foreign enterprises.

In general, the national origin of the enterprise is a very weak moderator of the observed relationships. In doing so, moderate effect occurs in only a few relationships. The direction of moderation is changeable: some relations are stronger in enterprises from Bosnia and Herzegovina, while some relations are stronger in foreign enterprises. Previous findings can be considered as an answer to the research question RQ2.

\section{Hypotheses verification}

As already mentioned, in this paper, research was conducted with the aim of determining the influence of leadership on the mutual trust of employees in enterprises in Bosnia and Herzegovina. Specifically:

H1: There are statistically significant correlati- ons between leadership dimensions and interpersonal trust at work dimensions.

H2: There is a statistically significant predictive effect of leading dimensions (independent variables) to interpersonal trust at work dimensions (dependent variables).

In addition to two hypotheses, two research questions were also put forward in the paper. Research questions are set in the research areas where moderate factors are examined because it is very difficult to assume the final result in advance. Specifically:

RQ1: The modernization of the ownership structure of the enterprise, the relation of leadership dimensions and interpersonal trust at work dimensions, is expressed in several relations. Consequently, it is not possible to make a general conclusion as to how the ownership structure of an enterprise acts as a moderator in relation to the dimensions of leadership and the dimensions of mutual trust at work

RQ2: The modernizing effect of the national origin of the enterprise on the relationship of leadership dimensions and interpersonal trust at work dimensions occurs only in one of the several observed pairs, based on which it can be concluded that there is no moderate effect of the national origin of the enterprise on the observed relationships.

\section{CONCLUSION}

Consulted literature for the purpose of writing this paper, as well as the results of the conducted research, confirm the conclusion that the desirable behaviour of the leader has a positive relationship with the numerous individual, organisational and business performances of the enterprise of different organisational structures, and thus with the mutual trust of the employees as one of the key organisational performance of the enterprise.

Specific research has found that leaders in Bosnia and Herzegovina enterprises have highperformance expectations, and they do not have too much understanding, support, and feelings for employees. This should be added to the fact that the penalties are more frequent than the rewards, and that LMX is about the average. All this points to a rather poor overall situation when it comes to leadership in enterprises in Bosnia and Herzegovina. In such circumstances, it is quite logical that the dimensions of mutual trust do not 
have a high average grade. In addition to the above, and when it comes to employees themselves in enterprises in Bosnia and Herzegovina, the basic observation is that they do not like a high distance of power, but rather overreact to good interpersonal relationships, both with their superiors and colleagues. It is a strong motivator for employees and leaders in Bosnia and Herzegovina enterprises.

Further results confirmed that awards really raise the level of mutual trust. Likewise, the strategic capabilities of the leader (reflected in the dimension L1 Core transformational leader behaviour) really contribute to improving the enterprise's strategic position in the market. On the other hand, insisting on high-performance leaders, as well as the application of the penal system, does not contribute to the improvement of mutual trust among employees.

Bearing in mind all the above, some recommendations can be made for leaders and managers in enterprises in Bosnia and Herzegovina. First of all, they should be aware of their important roles in securing high performance of businesses, both business and organisational. In particular, they should reduce their high expectations in terms of performance, reduce punishments, improve their relationship with employees, foster good relationships among employees, increase awards (to the extent possible), improve themselves in their strategic knowledge, thoughts and actions, and to reduce focus on tasks in their future work and increase the focus on people who perform specific tasks. In doing so, they must also take care of their authority, and in particular, not to exaggerate by showing understanding for the personal feelings of employees, as this can lead to the relaxation of employees.

Finally, on the basis of everything stated in this paper, the general conclusion can be clearly stated that leadership in general, and especially LMX and transformational leadership, has greatly a significant positive impact on the scope and intensity of the desirable organisational behaviour, first of all on mutual trust, and so indirectly to other organisational and business performance of the enterprise.

\section{REFERENCES}

Avey, J.B., Avolio, B.J., \& Luthans, F. (2011). Experimentally analyzing the impact of leader positivity on follower positivity and performance. The Leadership Quarterly, 22(2), 282-294.

Carmeli, A., Schaubroeck, J., \& Tishler, A. (2011). How CEO empowering leadership shapes top management team processes: Implications for firm performance. The Leadership Quarterly, 22(2), 399. 411.

Carpenter, M.A., Geletkanycz, M.A., \& Sanders, W.G. (2004). Upper echelons research revisited: antecedents, elements, and consequences of top management team composition. Journal of Management, 30 (6), 749-778.

Colbert, A.E., Kristof-Brown, A.L., Bradley, B.H., \& Barrick, M.R. (2008). CEO transformational leadership: the role of goal importance congruence in top management teams. Academy of Management Journal, 51(1), 81-96.

Cook, J. and Wall, T. (1980). New work attitude measures of trust, organisational commitment and personal need non-fulfilment. Journal of Occupational Psychology, 53, 39-52.

Elenkov, D.S. (2002). Effects of leadership on organisational performance in Russian enterprises. Journal of Business Research, 55(6), 467-480.

Ensley, M.D., Pearce, C.L., \& Hmieleski, K.M. (2006). The moderating effect of environmental dynamism on the relationship between entrepreneur leadership behavior and new venture performance. Journal of Business Venturing, 21(2), 243-263.

Erdogan, B., \& Enders, J. (2007). Support from the top: supervisors' perceived organisational support as a moderator of leader-member exchange to satisfaction and performance relationships. Journal of Applied Psychology, 92(2), 321-330.

Graen, G.B., \& Uhl-Bien, M. (1995). Relationshipbased approach to leadership: Development of leader member exchange (LMX) theory of leadership over 25 years, applying a multilevel multidomain perspective. The Leadership Quarterly, 6(2), 219-247.

Hofmann, D.A., \& Jones, L.M. (2005). Leadership, Collective Personality, and Performance. Journal of Applied Psychology, 90(3), 509-522.

Howell, J.M., Neufeld, D.J., \& Avolio, B.J. (2005). Examining the relationship of leadership and physical distance with business unit performance. The Leadership Quarterly, 16(2), 273-285.

Ling, Y., Simsek, Z., Lubatkin, M.H., \& Veiga, J.F. (2008a). The impact of transformational CEOs on the performance of small- to medium-sized firms: Does organisational context matter? Journal of Applied Psychology, 93(4), 923-934.

Ling, Y., Simsek, Z., Lubatkin, M.H., \& Veiga, J.F. (2008). Transformational leadership's role in promoting corporate entrepreneurship: examining the CEO-TMT interface. Academy of Management Journal, 51(3), 557-576. 
MacKenzie, S.B., Podsakoff, Ph.M., Rich, G.A. (2001). Transformational and transactional leadership and salesperson performance. Journal of the Academy of Marketing Science, 29(2), 115-134.

Northouse, P. G. (2008). Leadership, theory and practice. IV Edition, p. 2. Data status, Beograd.

Pellegrini, E.K., \& Scandura, T.A. (2006). Leadermember exchange (LMX), paternalism, and delegation in the Turkish business culture: An empirical investigation. Journal of International Business Studies, 37(2), 264-279.

Podsakoff, Ph.M., MacKenzie, S.B., Moorman, R.H., \& Fetter, R. (1990). Transformational leader behaviors and their effects on followers' trust in leader, satisfaction, and organisational citizenship behaviors. The Leadership Quarterly, 1(2), 107-142.

Podsakoff, Ph.M., Todor, W.D., Grover, R.A., \& Huber, V.L. (1984). Situational moderators of leader reward and punishment behaviors: fact or fiction? Organisational Behavior and Human Performance, 34(1), 21-63.

Robbins, S.P., Judge, T.A. (2009). Organizaciono ponašanje, 12th Edition. Zagreb, Mate.

Strukan, E., Nikolić, M., Sefić, S. (2017). Impact of transformational leadership on business performance. Tehnički vjesnik - Technical Gazette, 24 (2), 435-444.

\title{
UTICAJ LIDERSTVA NA MEĐUSOBNO POVJERENJE ZAPOSLENIH U PREDUZEĆIMA U BOSNI I HERCEGOVINI
}

\begin{abstract}
U radu su prikazane teorijske osnove i rezultati konkretnog istraživanja uticaja dimenzija poslovnog liderstva na dimenzije međusobnog povjerenja zaposlenih u preduzećima u Bosni $i$ Hercegovini. Pored toga, ispitana su moderatorna dejstva vlasničke strukture i nacionalnog porijekla preduzeća na posmatrani odnos. Podaci su dobijeni anketiranjem 334 menadžera srednjeg nivoa iz 103 preduzeća u Bosni i Hercegovini. Cilj ovog istraživanja je bio da se na osnovu relevantnih pokazatelja utvrdi u kojoj mjeri liderstvo utiče na međusobno povjerenje zaposlenih, kao jedan od pokazatelja ukupne efektivnosti vođenja poslovnih procesa, što direktno utiče na obim i intenzitet organizacionih i poslovnih performansi preduzeća. Također, zadatak ovog istraživanja je bio da se na osnovu utvrđenih vrijednosti, liderima i menedžerima daju određene preporuke i smjernice u kojem pravcu u budućnosti trebaju ići. Osnovni zaključci ovog istraživanja su da lideri treba da smanje visoka očekivanja u pogledu performansi, da smanje kazne, da poboljšaju svoj odnos sa zaposlenima, da povećaju nagrade u skladu sa mogućnostima, i da se usavršavaju u svojim strateškim znanjima, razmišljanjima i akcijama.
\end{abstract}

Ključne riječi: Liderstvo, LMX, Međusobno povjerenje, Performanse, Bosna i Hercegovina. 